\title{
HUMAN SETTLEMENT IN POLISH TERRITORY DURING THE LAST GLACIAL MAXIMUM (CA 24,000-19,000 CAL. BP): THE CALM BEFORE A NEW DEAL
}

\author{
MARTA POŁTOWICZ-BOBAK ${ }^{1}$, DARIUSZ BOBAK ${ }^{2}$
}

\begin{abstract}
Human presence in Poland during the Late Pleniglacial is evidenced by Gravettian sites, mostly from Małopolska. Such settlement almost disappears from the archaeological record during the period between 24 and 19 ky cal. BP. Only a few sites from that period have been discovered - two workshops without absolute chronology, and some meagre records of settlement with uncertain dating to the LGM. The Polish territory was resettled in the $19^{\text {th }}$ and $16^{\text {th }}$ millennium cal. BP onward, the settlers being associated with the Epi-Gravettian and Magdalenian cultures.
\end{abstract}

Key words: LGM, settlement, Gravettian, Epi-Gravettian, Poland

\section{Introduction}

The Late Pleniglacial, and especially the LGM time, is a period of very distinct climatic changes that resulted in the gradual growth and transgression of the Scandinavian ice sheet as it expanded to its maximum extent. This brought significant environmental changes that affected both fauna and flora, resulting in an impact on the dynamics of human settlement and migration (Terberger, Street 2002; Gamble et al. 2004; Terberger 2013; Annan, Hargreaves 2013; Tallavaara et al. 2015).

The LGM in the eastern part of Central Europe - and in the Polish territory in particular - stands out as a transitional period, as evidenced by the drop in number of archaeological sites, changes in their size and structure, as well as shifts in population centres.

The paper presents evidence of settlement activity during the LGM climate impact as well as the results of an absolute chronology of artefacts from that period from southern Poland, and the directions of cultural contacts during that time.

\section{Materials}

The territory of southern Poland has produced well documented sites of Gravettian settlement (Fig. 1), which was present north of the Sudeten and Carpathian Mountains from an early stage of this culture's development. The oldest record comes from Lower Silesia, from the Henryków site. It is a small camp dated to about 30.0$34.7 \mathrm{ky}$ cal. BP. Radiocarbon measurements were calibrated in the OxCal v. 4.4 application (Bronk Ramsey 2009), using the IntCal20 14C age calibration curve (Reimer et al. 2020). Conventional dates are given according to laboratory records e.g. $17,400 \pm 310 \mathrm{BP}$, calendar dates date with abbreviation "ky", e.g. 23.8-23.1 ky cal. BP.) (Wiśniewski et al. 2015). This site is assigned to the Early Gravettian and should be linked with lands to the south of the Sudeten - Moravia and Lower Austria, which are considered to have been settlement refuges during glacial period (Wiśniewski et al. 2015). The Wójcice site in Upper Silesia is also linked to the older phase of the Gravettian - however, this classification is based solely upon techno-typological analysis, without absolute dates (Ginter 1966; Dagnan, Ginter 1970).

\footnotetext{
${ }^{1}$ University of Rzeszów, Institute of Archaeology, ul. Moniuszki 10, 35-015 Rzeszów, Poland; e-mail: mpoltowicz@lithics.eu, ORCID: 0000-0003-1973-4971

${ }^{2}$ Foundation for Rzeszów Archaeological Centre, ul. Moniuszki 10, 35-015 Rzeszów, Poland; e-mail: dbobak@lithics.eu, ORCID: 0000-0002-5216-6630
} 


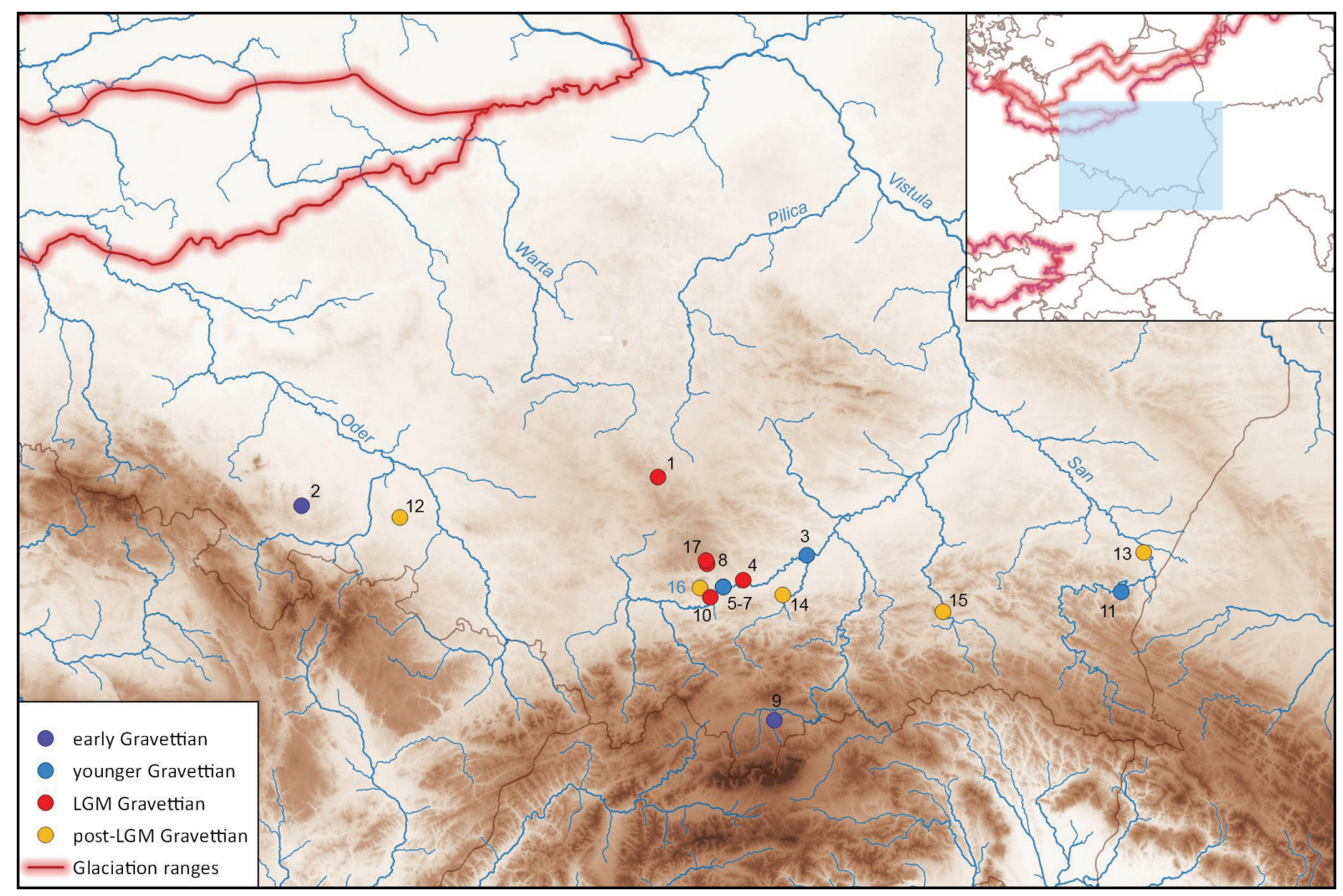

Fig. 1. Gravettian and Epi-Gravettian settlements in Poland

1 - Deszczowa, 2 - Henryków 15, 3 - Jaksice, 4 - Kraków-Nowa Huta, 5 - Kraków-Zwierzyniec 1, 6 - Kraków, ul. Spadzista B, 7 - Kraków, ul. Spadzista C, 8 - Mamutowa, 9 - Obłazowa, 10 - Piekary II, 11 - Przemyśl 2, 12 - Sowin 7, 13 - Święte 9 , 14 - Targowisko, 15 - Ujazd 6, 16 - Zawalona, 17 - Żytnia Skała

The Henryków site is still the sole known evidence for such early presence of Gravettian communities in Silesia. An early phase of settlement is also represented by the inventory from the layer VIII in Obłazowa Cave in the Carpathians, dated to $\mathrm{ca} 34 \mathrm{ky}$ cal. BP. Another group of finds that may be associated with the older phase of Gravettian settlement (if its taxonomic classification is correct) is from the Borsuka Cave from the Polish Jura. These finds, identified as a burial, are dated to between 31 and $29 \mathrm{ky}$ cal. BP (Wilczyński et al. 2016). This older settlement phase is associated with the so-called Pavlovian in reference to South-Moravian settlements (Moreau 2012). It should be pointed out that the date set for the Henryków site shows a much older chronology than the large camps in Moravia. So, the Henryków site appears to be more contemporaneous with the early Gravettian occupation of Lower Austria and south Germany. The origin of currently known materials pertains to this taxonomic unit (Moreau 2012; Wiśniewski et al. 2015; Bicho et al. 2017).

The prevailing scholarly opinion is that in this period Polish territories were an outlying periphery exploited by populations whose centres of settlement lay further south. Hence, the area to the north of the Carpathian Arc and the Sudeten was used solely for hunting or material-gathering expeditions (see Wiśniewski et al. 2015).

A later episode, best known from Małopolska, and particularly the Spadzista site in Cracow, is dated to $28.0-27.5 \mathrm{ky}$ cal. BP. This site, used repeatedly over many seasons, was both a campsite and a lithic industry workshop (Wilczyński 2007a, 2015a, b; Nývltová Fišáková 2013; Wojtal et al. 2015). The archaeological materials from this site show contacts between Małopolska on one hand and Central and West Slovakia on the other, including the population centre at Moravany nad Váhom, as well as between Małopolska and sites in North Moravia and Czech Silesia (Kozłowski 2001; Nývltová Fišáková 2013). Very sparse signs of Gravettian settlement at the Kraków-Zwierzyniec I site are linked to the camp at Spadzista site and dated to $c a 26.2 \mathrm{ky}$ cal. BP (Nadachowski et al. 2011; Wilczyński 2015a).

From that same period we also have the small site discovered at Jaksice in the Miechów Upland. This site yielded quite a broad range of 
absolute datings, i.e. 28.0-25.4 ky cal. BP (Wilczyński, Wojtal 2011; Wilczyński 2015b; Wilczyński et al. 2015).

It is possible that the Gravettian inventory excavated in Przemyśl at Słowackiego St. dates from the same period. It is associated, as with the complexes from Spadzista St. in Cracow, with the socalled Kostenki-Avdeyevian Culture (Kozłowski 1963; Sobczyk 1995).

Considering that the sites associated with the earlier phase of the Gravettian are associated with the Pavlovian and with the cultural phenomena of Moravia and Lower Austria, then the younger phase should be associated with the so-called Kostenki-Avdeyevian Culture. The existence of ties between Małopolska and Slovakia are evidenced by, for example, the large settlement complex at Moravany nad Váhom (Kozłowski 2001; Kaminská, Kozłowski 2002). The shift of Gravettian populations from Silesia to Małopolska is correlated with the changes to settlement and to migrations resulting from climate changes ongoing since the onset of the LGM. Similar processes had been observed in other areas of Central Europe (Połtowicz-Bobak 2013, further reading listed).

About 25,500 years ago, a rapid collapse of Gravettian settlement in Central Europe is observed. These processes also affected the Polish territory. Lands comprising Poland fit nicely into the debate concerning the total or not depopulation of Central Europe during the LGM (e.g. Housley et al. 1997; Street, Terberger 1999; Terberger, Street 2002; Terberger 2013). The period between 24,000 and 19,000 cal. BP is marked by an almost absolute disappearance of settlement over broad swathes of Europe - particularly to the north of the major mountain ranges - the Alps, the Sudeten and the Carpathians. Archaeological records from Poland that may be dated - with greater or lesser precision - to the period of LGM sensu stricto (LGM s.s.) (according to Demidenko 2020) are few and far between - not to mention, often with questionable dating. LGM s.s. is understood here as the period of maximum cold associated with the Leszno stage of the last glaciation.

The most significant and most often cited record of settlement from this period is the $\mathrm{C} 2$ site at Spadzista St. in Cracow. This site yielded a small inventory associated with the Gravettian from a layer dislocated by solifluction processes. The inventory, almost entirely manufactured from local Polish Jura flint, consists of numerous burins and backed blades plus a few scrapers. A few tools were made from chocolate flint whose outcrops are located over $100 \mathrm{~km}$ to the north-east, in the Holy Cross Mts. It seems reasonable to classify this site as a temporarily inhabited campsite. The ${ }^{14} \mathrm{C}$ dating produced a value of $17,400 \pm 310 \mathrm{BP}$ (Kozłowski, Sobczyk 1987; Sobczyk 1995), i.e. between 22.00 and $20.35 \mathrm{ky}$ cal. BP. Such chronological positioning was questioned by Terberger (2013). Newer research from the second decade of the $21^{\text {st }}$ century confirmed his doubts and called for a re-examination of both the chronological and cultural ties of this site (Wilczyński et al. 2012). A series of AMS datings from 2011-12 represents the $29^{\text {th }}$ and $28^{\text {th }}$ millennium BP, i.e. the time of most intense human occupation at the Spadzista site (Fig. 2, according to Wilczyński et al. 2012). A single later date $-20,200 \pm 350$ BP (25.26-23.39 ky cal. BP) - comes from a mammoth tusk (Nadachowski et al. 2011). The view accepted today is that the occupation episode at site $\mathrm{C} 2$ should be moved back in time to somewhere between 28 and $24 \mathrm{ky}$ cal. BP) (Wilczyński et al. 2015). There is a ${ }^{14} \mathrm{C}$ date of $19,450 \pm 120 \mathrm{BP}(23.77-23.10 \mathrm{ky}$ cal. BP) from materials accumulated at section $B$ of the site, specifically from the charred bone of an unidentified animal. This date is co-extant with other, much older datings (28.5-27.1 ky cal. BP) and is viewed as unreliable for the dating of that section of the site (Wojtal et al. 2015).

Sections B and B1 (layer 5) of the Spadzista site are considered to be of younger age. A lithic industry workshop has been documented there, and had probably also been used during the highest phase of the LGM. The characteristics of the inventory, particularly the core forms and manners of their working, point to this being an EpiGravettian site. The chronological brackets of the period during which the workshop was in use have been set quite broadly to $22.2-20.3 \mathrm{ky}$ cal. BP (Wilczyński 2007a), or even to $c a 18.5 \mathrm{ky} \mathrm{cal}$. BP (Kozłowski 1999). Hence it is highly probable that the site had been used even during the coldest period of the LGM, at that point solely as a workshop (Kozłowski 1999). The use of the workshop at the Piekary (site IIa layer 5) is also dated to the LGM s.s. The lithics working methods noted at that site are analogous to those observed at the Spadzista St. site in Cracow (Wilczyński 2006). However, no chronology of those two sites had been fixed with absolute datings, unless one counts the single date from Piekary site obtained from a reindeer bone and dated to 16,250 $\mathrm{BP}$ ( $c a$ 19.6 ky cal. BP) (Wilczyński 2015a) - these sites' chronology is based upon stratigraphic data, i.e. being deposited on top of older, dated layers (Spadzista site), and upon the age of the loess. The age of the Piekary site is estimated to be be- 
tween 23 and 18 ky cal. BP (Kozłowski 1999; Wilczyński 2006, 2007a). Both sites, if their chronology has been identified correctly, were used during the LGM s.s. and directly afterwards solely as workshops. This is an important observation to make, as at various points during the Palaeolithic both the Spadzista and the Piekary site had been used as camps.

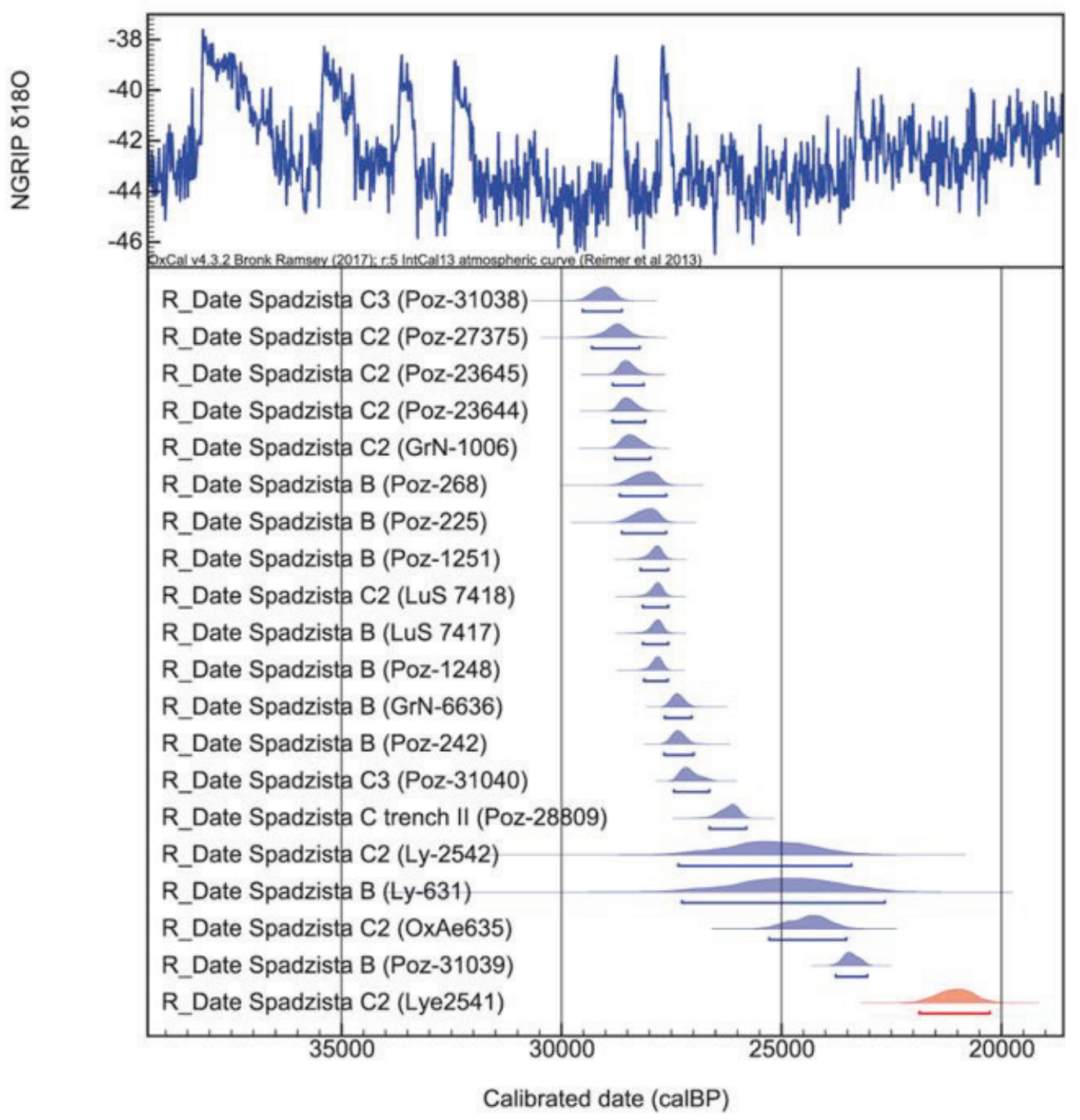

Fig. $2 .{ }^{14} \mathrm{C}$ dates from the Kraków-Spadzista $\mathrm{C} 2$ site

These two workshops also are the richest sites (in terms of number of artefacts) to be associated with the LGM s.s. There also are a few other locations in Poland which, with greater or lesser probability, were associated with the LGM. All these other sites - regardless of whether they are openair sites or caves - are low in artefact quantity.

One such location is the open-air site at Kraków-Nowa Huta, interpreted to be a mammothkilling site. It yielded mammoth remains and a meagre inventory of only ten items - and so uncharacteristic that it cannot be placed in taxonomic terms. Its age has been established between 24.1 and $21.8 \mathrm{ky}$ cal. BP based on stratigraphic data only (Kozłowski et al. 1970; Kozłowski 1990,
1999). However, datings of analogous sediment from some $1.5 \mathrm{~km}$ away produced ${ }^{14} \mathrm{C}$ datings of 27,750 BP (31.83-31.50 ky cal. BP), thus undermining such a late chronology (Wilczyński 2015a).

Yet another site with evidence of human activity attributed to the LGM period is the multilevel site at the Deszczowa Cave in the central part of the Polish Jura (Cyrek et al. 2000). There, layer VIIIa yielded vestiges of a fireplace and a small lithic inventory ( 22 items) plus a few items made from bone. The archaeological record is accompanied by animal bones. Reindeer antlers provided a ${ }^{14} \mathrm{C}$ dating of $17,480 \pm 150 \mathrm{BP}(21.72-20.76 \mathrm{ky} \mathrm{cal}$. $\mathrm{BP})$. As the antlers do not bear any signs of human 
industry these cannot be unequivocally associated with the archaeological record.

A later date - 16,150 \pm 280 BP (20.21-18.88 ky cal. BP) comes from another archaeological stratum of the very same VIIIa layer. Here again, it comes from reindeer bones without anthropogenic traces. The accompanying inventory is low in number and of undetermined taxonomical provenance. Layer VIII also includes an unworked grouse bone dated to $19,250 \pm 120 \mathrm{BP}$ (23.73-22.94 ky cal. BP). Such a chronology confirms the LGM age of this layer, but is highly divergent from the datings of the reindeer antlers and bones, thus additionally questioning their value in dating the manmade artefacts. Nevertheless, all three dates fall on the LGM s.s. period. But, as already alluded to above, there is no certainty of those dates actually being related with the human archaeological record, and thus there is no clear answer as to what these dates indicate exactly.

The situation at the Żytnia Skała site is similar, identified as a short-lived hunting campsite (Kozłowski 1999). It produced a small inventory of only 12 artefacts (blades and flakes plus a scraper with high edge scraper). The sole ${ }^{14} \mathrm{C}$ date $(20,080 \pm 320$ BP, i.e. $25.09-23.35 \mathrm{ky} \mathrm{cal}$. BP) was provided by a bone with no signs of intentional working (Verpoorte 2004, 2009).

The Mamutowa Cave site should also be mentioned in the context of LGM settlement. The inventory from layer 2 (a level of loess mixed with rubble) is dated using geological data and a ${ }^{14} \mathrm{C}$ date set of bones $(20,260 \pm 250$ BP, i.e. $25.03-23.81$ ky cal. BP and 11,650 \pm 200 BP, i.e. 14.02-13.16 ky cal. BP) to a broad period between the $25^{\text {th }}$ and $13^{\text {th }}$ millennium BP (Kozłowski, Kozłowski 1996; Kozłowski 1999; Wilczyński 2015a). The dating $20,260 \pm 250$ BP (25.03-23.81 ky cal. BP) places the inventory in the LGM s.s. The inventory is a mix of materials from different periods and from various cultural traditions, including the Gravettian and Epi-Gravettian (bidirectional cores, burins, backed blades, as well as pendants of mammoth ivory). According to Wilczyński (2016) the site should be associated with the Gravettian. Even if human presence during the LGM s.s. cannot be excluded, nor too can it be proven.

The final noteworthy site is the Dziadowa Skała Cave in the central section of the Polish Jura. The single artefacts found there during exploration in the 1950s are poorly documented, including in stratigraphic terms, making it difficult to place them in a chronological context. Chmielewski (1958) considered the items located in the upper sand layer to come from the Late Pleistocene, while some single artefacts (a backed point, accompanied by knapping chip and blade) should be associated with either Gravettian or Epi-Gravettian traditions. Nevertheless, it appears that today there is no basis for either chronological or taxonomic assignment of these finds. Furthermore, these should probably be assigned to one of the younger periods and cultural traditions (Wilczyński 2015a). The same applies to finds from several other sites noted in the pertinent literature (e.g. the Jasna Cave).

\section{Discussion}

The above brief overview of sites from the Polish territory associated with settlement during the main phase of the LGM shows that the human penetration between $24 \mathrm{ky}$ and $19 \mathrm{ky}$ cal. BP is a highly complex issue that is open to discussion.

Among the aforementioned sites there is none with a chronology determined with reliable absolute datings (Table 1). The dates at our disposal are not unquestionably connected with human occupation. The sole site that until not so long ago was perceived by many authors to be best supported by ${ }^{14} \mathrm{C}$ datings actually turned out to pre-date the LGM. Similarly, some other sites whose chronology had been regarded as probable signs of human presence during the LGM should also be excluded from analysis. The date set from Zawalona Cave site is close to the discussed period: the older datings are at the limit of the period covered by this paper (Alexandrowicz et al. 1992). The chronology of other sites is based on indirect references.

The data that we possess today points to human settlement from the younger phase of the Gravettian, known chiefly from sites located in Małopolska (Spadzista, Jaksice, Deszczowa Cave layer VII), to reach into the LGM early stage; afterward, before $c a 24,000$ cal. BP onwards, human presence practically disappears.

Nevertheless, it seems that human presence during the period 24-19 $\mathrm{ky} \mathrm{cal}$. BP in the southern Polish territory can be regarded as probable, even if its exact chronology cannot be pinpointed. It is likely that this area, lying relatively far north and thus quite near $(\mathrm{ca} 250 \mathrm{~km})$ to the ice sheet margin during the Weichselian Leszno (Brandenburg) Stage, was not fully abandoned by humans even in the period of the Scandinavian ice sheet maximum extent and the associated climate and environmental changes. This points, however, to these lands having been at the absolute edge of the ecumene and only sporadically used, for highly specific 
purposes, by small groups of hunter-gatherers whose more established habitation was located elsewhere. All remnants of human occupation known to date are situated in a fairly limited area, i.e. the southern and central sections of the Polish Jura. Two functional types of sites may be discerned: 1) large, most likely repeatedly used work- shops, 2) smaller, possibly less appointed cave, sporadically and briefly used as a hunting camp (Kozłowski 2007; Połtowicz-Bobak 2013). Although the usage of the former seems to be quite well documented, the use of the latter is subject to a yet-unresolved scholarly debate.

Table 1

Absolute dates of LGM sites

\begin{tabular}{|l|l|c|c|l|}
\hline \multicolumn{1}{|c|}{ Site } & \multicolumn{1}{|c|}{$\begin{array}{c}\text { Radiocarbon } \\
\text { determination }\end{array}$} & \multicolumn{1}{c|}{ cal BP } & Material & \multicolumn{1}{c|}{ References } \\
\hline Deszczowa Cave & $\begin{array}{l}16,150 \pm 280 \\
(\mathrm{GdA}-964)\end{array}$ & $20,210-18,880$ & reinder bone (unworked) & Cyrek et al. $(2000)$ \\
\hline Deszczowa Cave & $\begin{array}{l}17,480 \pm 310 \\
(\mathrm{Gd}-10212)\end{array}$ & $21,720-20,760$ & reinder antler (unworked) & Cyrek et al. (2000) \\
\hline Piekary II & $16,250(\mathrm{bd})$ & $c a 19,600$ & reinder bone (unworked) & Wilczyński (2015a) \\
\hline Mamutowa cave & $\begin{array}{l}20,260 \pm 250 \mathrm{BP} \\
(\mathrm{Gd}-10021)\end{array}$ & $25,030-23810$ & bone & Wilczyński (2015a) \\
\hline Mamutowa cave & $\begin{array}{l}11,650 \pm 200 \mathrm{BP} \\
(\mathrm{Gd}-10024)\end{array}$ & $14,020-13,160$ & bone & Wilczyński (2015a) \\
\hline Żytnia Skała Cave & $\begin{array}{l}20,080 \pm 320 \\
(\mathrm{OxA}-6563)\end{array}$ & $25,090-23,350$ & bone (unworked) & Kozłowski (1999) \\
\hline
\end{tabular}

It is our belief that even if human presence in this area and in this period is likely, it still cannot be proven. Both chronological data - and this including the fact that ${ }^{14} \mathrm{C}$ dating can never be clearly and indubitably linked with human activity - as well as the ambiguity of archaeological material, preclude a positive or negative answer to this issue. Yet another argument against the assignment of the aforementioned sites to the Epi-Gravettian is the fact that people from these cultural communities seem to have preferred open-air camps (Nerudová, Moník 2019), whereas here we have a sample heavily skewed towards cave sites. Additionally, no unquestionably Epi-Gravettian open-air sites from this period are known, with such appearing only after the main stage of the LGM. In the opinion of Wilczyński (2006, 2007a, b, 2015a), the workshops from the Spadzista St. site and from the Piekary site could be associated with the EpiGravettian, this being hinted by the technological aspects of the inventories. As to the other sites, their small sizes usually rule out an unequivocal answer to this question.

It is worthwhile asking what the purpose was of those forays into southern Poland. Where did those hunter-gatherers exploring lands to the north of the Carpathian Arc live? The current view is that one should look for settlement refugia during the glacial period in Slovakia and Czechia (Wiśniew- ski et al. 2017) and possibly also in Ukraine (Wilczyński 2007a). The best documented Slovakian site dating to this period is the large camp at the Kašov site (Bánesz et al. 1992; Novák 2004; Novak 2006). This site preserved two archaeological layers: the lower, Late Gravettian, providing a date of 20,700 \pm 350 BP (25.78-24.10 ky cal. BP), and the upper, Epi-Gravettian, with a date of 18,600 \pm 390 BP (23.72-21.47 ky cal. BP) (Novák 2004). Hence, both settlement horizons occur during the LGM sensu stricto. The lower, Gravettian layer, is associated with shouldered poits facies, i.e. the very same variety of the Gravettian as found at the Spadzista St. site in Cracow and at the Moravany nad Váhom sites in western Slovakia. The settlement at Kašov is, however, younger than the aforementioned campsites and - if one goes with the suggested chronology - older than the workshops; nevertheless one cannot rule out that the workshops at the Spadzista St. site functioned in that period as well, this being suggested by the imports of Polish Jura flint found in large number in the older layer at Kašov (Novák 2004). At the same time one should note that in the EpiGravettian layer the structure of raw materials changes radically, now evidently dominated by locally acquired obsidian (Novák 2004; Bánesz et al. 1992). Both Gravettian and Epi-Gravettian sites are known from the areas to the east and south-east 
of Małopolska, including those used during the LGM s.s., such as Ukrainian Molodove V (layer 7-4), Doroshivtsi III (layer 2-6) or Moldavian Cosautsy (layer 10-1d) (Nuzhnyj, Pyasec'kyj 2003; Haesaerts et al. 2007, 2019; Cyrek, Sytnyk 2012; Sytnyk 2015; Nuzhnyj 2015; Kulakovska et al. 2015).

It may be hypothesised that the most valuable resource of Małopolska was flint, the acquisition of which was the driving reason behind the penetration of this area by hunter-gatherers during the LGM s.s. This is supported by the existence of intensively, and probably repeatedly, used workshops at Spadzista St. in Cracow and Piekary. Interestingly, these sites, previously multi-purpose, were in that period used exclusively in their workshop capacity.

The question of whether the relevant area could have been used as hunting grounds is difficult to answer. Assuming that those lands were subject to brief penetration by small groups dedicated to a specific task, it is difficult to speculate whether the remains of hunting campsites with very meagre inventories discovered in caves are evidence of hunting expeditions or are a side-line to flint-gathering forays.

Identification of areas supplied by materials from those Małopolska workshops is a problem. Flint from the Polish Jura near Cracow has been found in the lower layer of the Kašov site in eastern Slovakia, but there are no signs of it in the upper layer - as it seems that only local material was used there (Bánesz et al. 1992; Novák 2004; Kaminská 2014). Pinpointing ties between workshops using technological or typological features of the inventories is problematic. Yet another difficulty is posed by the fact that, during the LGM, Epi-Gravettian communities tended to rely upon local resources: imports played a minor role $(\mathrm{Ne}-$ rudová 2015; Nerudová, Moník 2019).

In the opinion of scholars studying the issue, one should search for such ties in lands to the east of the Polish territory. Such a line of thought is suggested by typological inspiration noted at, for example, sites such as Spadzista St. in Cracow or Piekary (Wilczyński 2006). At the same time, no presence of Polish Jura flint has been noted at west-Ukrainian Late Gravettian or Epi-Gravettian sites. The lithic industry there is based upon local, high quality resources (Cyrek, Sytnyk 2012; Sytnyk 2015). This is in line with the resource procurement strategy observed during the Epi-
Gravettian, i.e. the focus upon local sources. This look at possible ties between Małopolska and eastern Europe also merits attention due to southern Poland's location on the archaeological culture map of Europe both during the LGM and immediately after.

Re-settlement of Poland is attested from the $19^{\text {th }}$ millennium cal. BP (Fig. 3). Here the salient sites are the Epi-Gravettian Targowisko no. 10 with dates from 18.5 to $16.6 \mathrm{ky}$ cal. BP (Wilczyński 2009; Połtowicz-Bobak 2013) - and the younger Sowin (lower layer), whose chronology is established by OSL dating at between 15,470 \pm 860

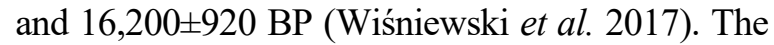
chronology of the Zawalona Cave site, although still being discussed, should be placed in the period directly after the LGM. Human presence between 19.5 and $18.0 \mathrm{ky}$ cal. BP is suggested by two datings: $15,380 \pm 340 \mathrm{BP}$ and $14,060 \pm 240 \mathrm{BP}$, i.e. 19.50-18.01 ky cal. BP and 17.85-16.39 ky cal. BP. Even though the older of those dates - considering the margin of error - does overlap the times preceding $19 \mathrm{ky} \mathrm{cal}$. BP, the dates are nevertheless younger and thus should be associated with a later period (GS-2a). Additionally, the time gap between these dates and those from unworked bones greatly limits their value in discussions of the possible settlement of southern Poland before its recolonisation after the LGM. The unearthed inventory, assigned to the Epi-Gravettian, is very limited and cannot be taxonomically identified (Alexandrowicz et al. 1992).

The taxonomic identity of the artefacts of the Ujazd site (Jasło District) in the Ciężkowice Foreland is unclear (Pawłowska et al. 2003; Valde-Nowak et al. 2005). It is probably not Epi-Gravettian. Most of the artefacts are debitage gathered on a secondary layer. The identified tools include two massive perforators, a burin and drill, plus two scrapers: nose-shaped and high-edged. The stratigraphy of this site is distorted. Two TL datings from the trench profile provided an age of $18,600 \pm 3,100 \mathrm{BP}$ and $15,100 \pm 1,700 \mathrm{BP}$, with the older date coming from a sample taken from a higher sediment unit. This is probably a site populated after the peak of the LGM, although this cannot be affirmed with certainty.

The youngest Epi-Gravettian site in Poland is Święte in Subcarpathia in eastern Poland, indirectly dated by OSL dating of underlying loess to a period younger than 15,500 $\pm 1,200$ BP (Poktowicz-Bobak et al. 2018). 


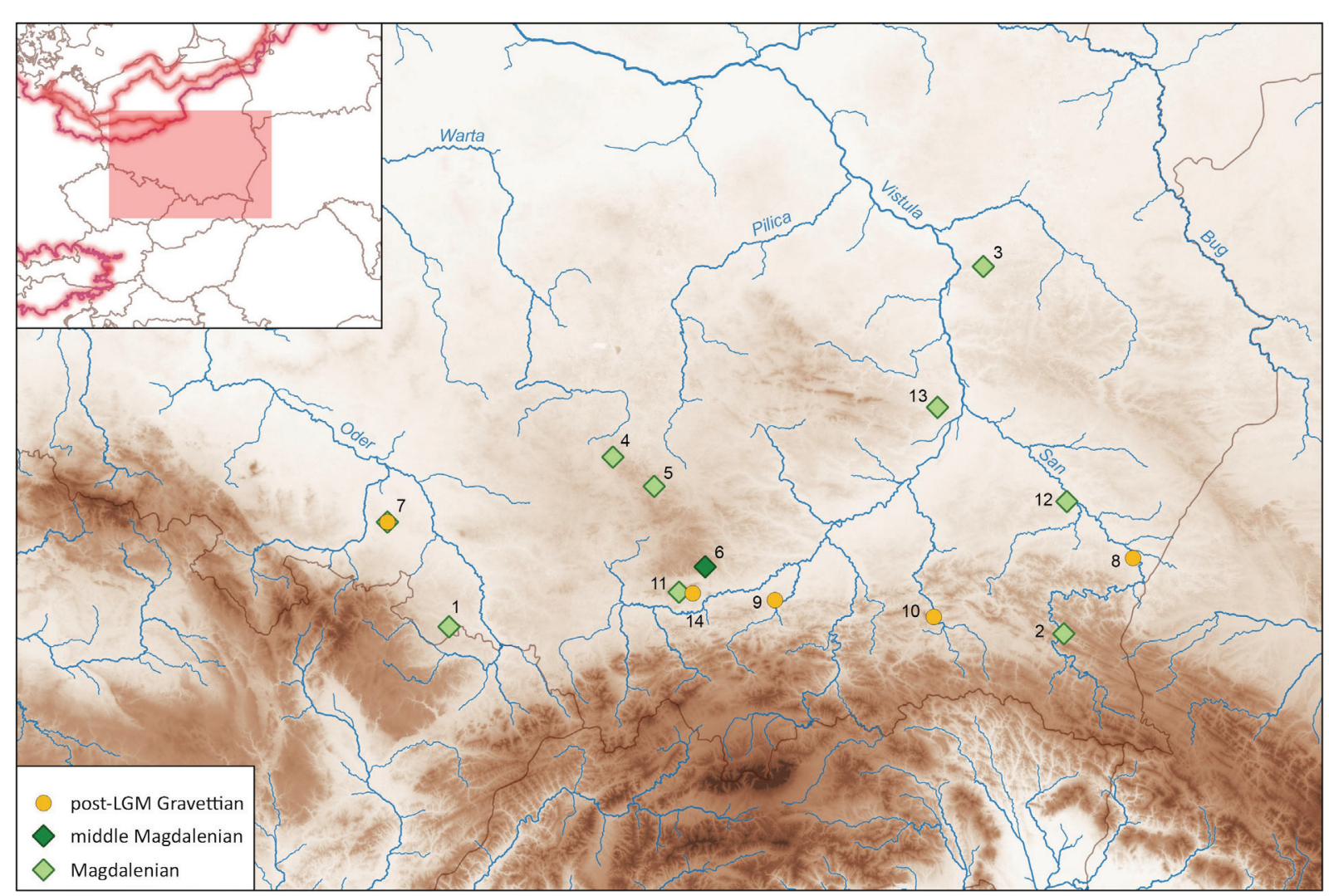

Fig. 3. Settlement after LGM in Poland

1 - Dzierżysław 35, 2 - Hłomcza, 3 - Klementowice 20, 4 - Komarowa, 5 - Krucza Skała, 6 - Maszycka, 7 - Sowin 7 , 8 - Święte 9, 9 - Targowisko, 10 - Ujazd 6, 11 - W Zalasie, 12 - Wierzawice, 13 - Wilczyce, 14 - Zawalona

\section{Conclusions}

The presented records of human presence during the LGM and its immediate wake outlined above are highly relevant as they show that Polish lands, located in an area extremely adverse to human settlement, were not totally anecumene. It does seem that human penetration of the area during the period of about 24-19 ky cal. BP was limited to the procurement of raw materials. It is not possible to prove any other use of this area in that period. There is simply a dearth of records of settlement - be these longer, of seasonal length (such lack being quite natural), or even of briefly used hunting campsites.

Analysis of the available data indicates the presence of Gravettian groups in the Polish territory at the beginning of the LGM, and later abandonment of the area due to worsening climatic conditions. It seems that at the maximum icesheet transgression during the Leszno Phase (after 25.5 ky cal. BP) (Marks 2002), human habitation disappeared almost entirely, with the area being used mostly (or maybe solely?) as a source of flint. The return of human presence after 19-18 ky cal. BP is unquestionable. At this point com- munities representing two different cultural traditions appear - the Epi-Gravettian best represented at the Targowisko site, and the Magdalenian discovered at the Maszycka Cave site. These two cultural units also coexisted in the period when southern Poland was occupied by populations associated with the later Magdalenian (Wiśniewski et al. 2017).

In this context, it is worth pointing to the breakdown of Epi-Gravettian inventories by origin of raw materials, particularly those at Targowisko site (Wilczyński 2009, 2014) and the significantly younger Święte site (Połtowicz-Bobak et al. 2018). The lithic inventory from Targowisko includes materials identified as being proof of ties with lands to the south of the Carpathians; similarly, at Ujście, part of the materials came from the south. The inventory at Święte consists entirely of Volynian flint, a material whose outcrops are located to the east of the Polish territory. In all the above cases, we are talking about areas where traces of the Magdalenian Culture are unknown, yet with records of Epi-Gravettian settlement. This provides strong pointers as to the origins of Epi-Gravettian groups exploring the south of Polish territory after the passage of the coldest phase of the LGM - these 
are the same as those mentioned during the peak of the LGM. Magdalenian populations spread into Poland from the west (Maszycka) and Moravia (late Magdalenian) (Połtowicz-Bobak 2013).

It is thus highly likely that Magdalenian people coming to Poland occupied areas constantly inside the orbit of Epi-Gravettian settlement. Southern and south-eastern Poland were areas where those two cultural traditions came into contact and where - for some time - the two coexisted side by side (Wiśniewski et al. 2017; Połtowicz-Bobak in press). Whether those contacts were intense - and how intense - and what impact they had on those cultures, are questions that remain to be answered.

\section{References}

Alexandrowicz S.W., Drobniewicz B., Ginter B., Kozłowski J.K, Madeyska T., Nadachowski A., Pawlikowski M., Sobczyk K., Szyndlar Z., Wolsan M. 1992. Excavations in the Zawalona cave at Mników (Cracow Upland, Southern Poland). Folia Quaternaria 63: 43-77.

Annan J.D., Hargreaves J.C. 2013. A new global reconstruction of temperature changes at the Last Glacial Maximum. Climate of the Past 9,1: 367-376.

Bánesz L., Hromada J., Desbrosse R., Margerand I., Kozłowski J.K., Sobczyk K., Pawlikowski M. 1992. Le site de plein air du Paléolithique supérieur de Kašov I en Slavaquie orientale. Slovenska Archeologia XL,1: 5-28.

Bicho N., Cascalheira J., Gonçalves C. 2017. Early Upper Paleolithic colonization across Europe: Time and mode of the Gravettian diffusion. PLOS ONE 12,5: e0178506.

Bronk Ramsey C. 2009. Bayesian analysis of radiocarbon dates. Radiocarbon 51(1): 337-360.

Chmielewski W. 1958. Stanowisko paleolityczne w Dziadowej Skale koło Skarżyc w pow. zawierciańskim. Prace $i$ Materiaty Muzeum Archeologicznego i Etnograficznego w Lodzi, Seria Archeologiczna 3: 5-61.

Cyrek K., Sytnyk O. 2012. Graweckie stanowisko w Haliczu (Halycu) na Ukrainie. Wyniki polsko-ukraińskich badań wykopaliskowych. Acta Universitatis Nicolai Copernici, Archeologia XXXII: 5-55.

Cyrek K., Nadachowski A., Madeyska T., Bocheński Z., Tomek T., Wojtal P., Miękina B., Lipecki G., Garapich A., Rzebik-Kowalska B., Stworzewicz E., Wolsan M., Godawa J., Kościów R., Fostowicz-Frelik Ł., Szyndlar Z. 2000. Excavation in the Deszczowa Cave (Kroczyckie Rocks, Częstochowa Upland, Central Poland). Folia Quaternaria 71: 5-84.
Dagnan A., Ginter B. 1970. Wyniki badań na stanowisku górnopaleolitycznym w Wójcicach, pow. Grodków. Sprawozdania Archeologiczne XXII: 31-37.

Demidenko Y.E. 2020 (in press). South of Eastern Europe and Upper Paleolithic diversity around the Last Glacial Maximum. Quaternary International.

Gamble C.S., Davies W., Pettitt P., Richards M. 2004. Climate change and evolving human diversity in Europe during the last glacial. Philosophical Transactions of the Royal Society 359: 243-254.

Ginter B. 1966. Stanowisko górnopaleolityczne w Wójcicach, pow. Grodków. Materiaty Archeologiczne 7 : 59-65.

Haesaerts P., Borziac I., Chirica V., Damblon F., Koulakovska L. 2007. Cadre stratigraphique et chronologique du Gravettien en Europe centrale. PALEO. Revue d'archéologie préhistorique $19: 31-52$.

Haesaerts P., Gerasimenko N., Damblon F., Yurchenko T., Kulakovska L., Usik V., Ridush B. 2019. The Upper Palaeolithic site Doroshivtsi III: a new chronostratigraphic and environmental record of the Late Pleniglacial in the regional context of the Middle Dniester-Prut loess domain (Western Ukraine). Quaternary International 546: 196-215.

Housley R.A., Gamble C.S., Street M., Pettitt P.B. 1997. Radiocarbon evidence for the Lateglacial recolonisation of Northen Europe. Proceedings of the Prehistoric Society 63: 25-54.

Kaminská L. (ed.). 2014. Stare Slovensko. Paleolit a mezolit, t. 2. Archaeologica Slovaca Monographiae, t. 2, Nitra.

Kaminská L', Kozłowski J.K. 2002. Gravettian settlement on the south side of the Western Carpathians. In J. Gancarski (ed.) Starsza i środkowa epoka kamienia w Karpatach polskich. Krosno: 35-58.

Kozłowski J.K. 1963. Z zagadnień paleolitu Polski południowo-wschodniej. Rocznik Województwa Rzeszowskiego III: 5-18.

Kozłowski J.K. 1990. Northern Central Europe c. 18000 BP. In O. Soffer, C.S. Gamble (eds) The World at $18000 \mathrm{BP}$, t. 1-Hight Latitudes, Oxford.

Kozłowski J.K. 1999. Les origines de la récolonisation de la partie septentrionale de 1 'Europe Centrale après le pléniglaciaire. Folia Quaternaria 70 : 317-331.

Kozłowski J.K. 2001. Dwa mikroregiony osadnictwa późnograweckiego: dolina Wisły pod Krakowem oraz dolina Wagu pod Piešt'ianami. In: J.K. Kozłowski, E. Neustupny (eds) Archeologia przestrzeni. Metody $i$ wyniki badań struktur osadniczych $w$ dorzeczach górnej Łaby $i$ Wisty. Polska Akademia Umiejętności, Akademie Věd České Republiky, Kraków: 95-110. 
Kozłowski J.K. 2007. Le Gravettien du nord des Carpathes et des Sudètes. Paléo 19 : 221-242.

Kozłowski J.K., Kozłowski S.K. 1996. Le Paléolithique en Pologne. Grenoble.

Kozłowski J.K., Sobczyk K. 1987. The Upper Palaeolithic Site Kraków-Spadzista Street C2. Excavations 1980. Prace Archeologiczne 42: 7-68.

Kozłowski J.K., Kubiak H., Welc A. 1970. A Palaeolithic site with mammoth remains at Nowa $\mathrm{Hu}-$ ta. Folia Quaternaria 36: 1-27.

Kulakovska L., Usik U., Haesaerts P., Ridush B., Uthmeier T., Hauck T.C. 2015. Upper Paleolithic of Middle Dniester: Doroshivtsi III site. Quaternary International 359-360: 347-361.

Marks L. 2002. Last Glacial Maximum in Poland. Quaternary Science Reviews 21: 103-110.

Moreau L. 2012. Le Gravettien ancien d'Europe centrale revisité : mise au point et perspectives. L'Anthropologie 116,5: 609-638.

Nadachowski A., Lipecki G., Wojtal P., Miekina B. 2011. Radiocarbon chronology of woolly mammoth (Mammuthus Primigenius) from Poland. Quaternary International 245: 186-192.

Nerudová Z. 2015. The example of the Epigravettian site of Brno-Štýřice III (Czech Republic). Anthropolgie LIII,1-2: 245-256.

Nerudová Z., Moník M. 2019. The Epigravettian of Kůlna Cave? A revision of artefacts. Archeologické rozhledy 71: 567-588.

Novák M. 2004. Gravettian occupation in the lower layer of Kašov I. In: J. Svoboda, L. Sedláčková (eds) The Gravettian Along the Danube, t. 11. Dolnověstonické Studie, Brno: 217-242.

Novak M. 2006. Priestorová analýza paleolitických sídlisk. Distribúcia artefaktov na gravettienskych sídliskách Pavlov a Kašov. Přehled výzkumů 47: 49-68.

Nuzhnyj D.Yu. 2015. Verxnij paleolit Zaxidnoyi i Pivnichnoyi Ukrayinы (texniko-typolohichna variabel"nist" ta periodyzaciya). Instytut Arxeolohiyi Nacional'noyi Akademiyi Nauk Ukrayiny, Kyyiv.

Nuzhnyj D.Yu., Pyasec'kyj V.K. 2003. Krem'yanyj kompleks verxn"opaleolitychnoyi stoyanky Barmaky na Rivnenshhyni ta problema isnuvannya pam'yatok mizyns"koyi industriyi na Volyns"kij vysochyni. Kam'yana doba Ukrayiny 2: 58-74.

Nývltová Fišáková M. 2013. Seasonality of Gravettian sites in the Middle Danube Region and adjoining areas of Central Europe. Quaternary International 294: 120-134.

Pawłowska M., Petrykowski S., Valde-Nowak P. 2003. Verification surface studies of the Upper Palaeolithic site at Ujazd county of Jasło (Poland). Praehistoria, Miscolc 4-5: 153-164.

Połtowicz-Bobak M. in press. Eastern border of the Magdalenian Culture - an area of settlement or resource gathering? Anthropologie.
Połtowicz-Bobak M. 2013. Wschodnia prowincja magdalenienu. Wydawnictwo Uniwersytetu Rzeszowskiego, Rzeszów.

Połtowicz-Bobak M., Bobak D., Łanczont M., Mroczek P., Komar M., Nowak A., Standzikowski K. 2018. Late Glacial environment and Late Palaeolithic settlement in the San River Valley (SE Poland). presented on Central European Conference on Geomorphology and Quaternary Sciences, 2018, Gissen, Niemcy.

Reimer P.J., Austin W.E.N., Bard E., Bayliss A., Blackwell P.G., Ramsey C.B., Butzin M., Cheng H., Edwards R.L., Friedrich M., Grootes P.M., Guilderson T.P., Hajdas I., Heaton T.J., Hogg A.G., Hughen K.A., Kromer B., Manning S.W., Muscheler R., Palmer J.G., Pearson C., Plicht J. van der, Reimer,R.W., Richards D.A., Scott E.M., Southon J.R., Turney C.S.M., Wacker L., Adolphi F., Büntgen U., Capano M., Fahrni S.M., Fogtmann-Schulz A., Friedrich R., Köhler P., Kudsk S., Miyake F., Olsen J., Reinig F., Sakamoto M., Sookdeo A., Talamo S. 2020. The IntCal20 Northern Hemisphere Radiocarbon Age Calibration Curve (055 cal ka BP). Radiocarbon 62: 725-757. https://doi.org/10.1017/RDC.2020.41

Sobczyk K. 1995. Osadnictwo wschodniograweckie w dolinie Wisły pod Krakowem. Rozprawy Habilitacyjne - Uniwersytet Jagielloński, nr 303, Kraków.

Street M., Terberger T. 1999. The last Pleniglacial and the human settlement of Central Europe: new information from the Rheinland site of Wiesbaden - Igstadt. Antiquity 73: 259-272.

Sytnyk O. 2015. Paleolit Przedkarpacia i Podola: kontekst archeologiczny, geochronolgiczny, kulturowy. In: M. Łanczont, T. Madeyska (eds.) $P a-$ leolityczna ekumena strefy Pery- $i$ Metakarpackiej. Wydawnictwo UMCS, Lublin: 693-835.

Tallavaara M., Luoto M., Korhonen N., Järvinen H., Seppä H. 2015. Human population dynamics in Europe over the Last Glacial Maximum. Proceedings of the National Academy of Sciences 112,27: 8232-8237.

Terberger T. 2013. Le Dernier Maximum glaciaire entre le Rhin et le Danube, un réexamen critique. Mémoire de la Société préhistorique française LVI : 415-443.

Terberger T., Street M. 2002. Hiatus or continuity? News results for the question of Pleniglacial settlement in Central Europe. Antiquity 76: 691698.

Valde-Nowak P., Łanczont M., Pawłowska M. 2005. The Upper Palaeolithic Site at Ujazd (Polish Carpatians). Acta Archaeologica Carpathica XL: 5-26.

Verpoorte A. 2004. Eastern Central Europe during the Pleniglacial. Antiquity 78: 257-266.

Verpoorte A. 2009. Chronology of the Gravettian in Bohemia. In P. Šida (ed.) The Gravettian of 
Bohemia, t. 17. Dolnověstonické Studie, Brno: 44-58.

Wilczyński J. 2006. The upper palaolithic workshop at the site Piekary IIa sector XXII layer 5. Sprawozdania Archeologiczne 58: 175-203.

Wilczyński J. 2007a. The Gravettian and Epigravettian lithic assemblage from Kraków-Spadzista $\mathrm{B}+\mathrm{B} 1$ :dynamic approach to the technology. Folia Quaternaria 77: 37-96.

Wilczyński J., 2007b. Epigrawecka pracownia krzemienia na stanowisku Kraków ul Spadzista B+B1. Przeglad Archeologiczny 55: 5-52.

Wilczyński J. 2009. Targowisko - a new Late Glacial Site in Southern Poland. Eurasian Prehistory 6,1-2: 95-118.

Wilczyński J. 2014. Paleolityczne oraz mezolityczne wyroby kamienne ze stan. 10, 11 w Targowisku, pow. wielicki. In: A. Zastawny (ed.) Targowisko, stan. 10, 11. Osadnictwo z epoki kamienia. Via Archaeologica. Źródła z badań wykopaliskowych na trasie autostrady A4 w Małopolsce, Kraków: 21-61.

Wilczyński J. 2015a. The Gravettian and Epigravettian Settlement of Poland. In: S. Sázelová, M. Novak, A. Mizerová (eds) Forgotten Times and Spaces. New perspectives in paleoetnological and archeological studies. Institute of Archeology of the Czech Academy of Sciences; Masaryk University, Brno: 191-213

Wilczyński J. 2015b. A Gravettian Site in Southern Poland: Jaksice. ISEA PAS, Kraków.

Wilczyński J. 2016. Variability of Late Gravettian lithic industries in Southern Poland: a case study of the Kraków Spadzista and Jaksice II sites. Quaternary International 406:129-143.
Wilczyński J., Wojtal P. 2011. Jaksice II - a new Gravettian Site in southern Poland. Přehled výzkumů 52,1: 37-41.

Wilczyński J., Wojtal P., Sobczyk K. 2012. Spatial organization of the Gravettian mammoth hunters' site at Kraków Spadzista (southern Poland). Journal of Archaeological Science 39: $3627-$ 3642.

Wilczyński J., Szczepanek A., Wojtal P., Diakowski M., Wojenka M., Sobieraj D. 2016. A Mid Upper Palaeolithic Child Burial from Borsuka Cave (Southern Poland). International Journal of Osteoarchaeology 26:151-162.

Wilczyński J., Wojtal P., Sobieraj D., Sobczyk K. 2015. Kraków Spadzista trench C2: New research and interpretations of Gravettian settlement. Quaternary International 359-360: 96113.

Wiśniewski A., Płonka T. Jary Z., Lisa L., Traczyk A., Kufel-Diakowska B., Raczyk J., Bajer A. 2015. The early Gravettian in a marginal area: New evidence from SW Poland. Quaternary International 359-360: 131-152.

Wiśniewski A., Połtowicz-Bobak M., Bobak D., Jary Z., Moska P. 2017. The Epigravettian and the Magdalenian in Poland: New chronological data and an old problem. Geochronometria 44,1: $16-29$.

Wojtal P., Sobczyk K., Wilczyński J. 2015 A new look at an old site: studies of the Kraków Spadzista site 1968-2013.In: S. Sázelová, M. Novak, A. Mizerová (eds) Forgotten Times and Space. New perspectives in paleoanthropological, paleoethnological and archeological studies. Institute of Archeology of the Czech Academy of Sciences; Masaryk University, Brno: 169190. 